\title{
MAPPING SCHOOL BULLYING PADA ANAK DI KOTA SAMARINDA DENGAN EPI MAP
}

\author{
Rahmi Susanti ${ }^{1}$, Riza Hayati Ifroh ${ }^{2}$, Ika Wulandari ${ }^{3}$ \\ ${ }^{1,2,3}$ Fakultas Kesehatan Masyarakat, Universitas Mulawarman \\ rachmi.rachmat@gmail.com
}

\begin{abstract}
Elementary school students experience intimidation both physically and mentally as much as 80\%. There are 457 cases of sexual and child abuse that occurred in east borneo province, of which there are cases of bullying throughout the year 2015 ago. Student in adolescence in Samarinda city as much as 23\% have high level of bullying. The purpose of these research is to mapping of student bullying at public elementary school in Samarinda by using epi info, 2016. Descriptive study to analyze the pattern distribution of school bullying in Samarinda. The location of this study is in Samarinda, where respondents came from 30 public elementary schools in 10 districts. Determination of primary schools to questionnaire determined by local UPTD. The data were processed using Epi Info on the menu help Epi Map. The number of respondents who obtained consisting of 1,491 male and female students. The distribution of the numbers of school bullying was loaded into Samarinda's map that is divided into 10 districts. Map depicts figures based on chloropeth and dot density per area. Perpetrators of school bullying reaches 544 children and 769 victims of school bullying. districts with the highest offender is Samarinda cities namely $43.50 \%$ and districts with the highest casualties are welcome is $57.50 \%$. The formation of team competent anti school bullying can be done by the school in order to oversee the incidence of school bullying.
\end{abstract}

Keywords: Mental Health, Pattern Distribution, Children

\begin{abstract}
ABSTRAK
Siswa sekolah dasar mengalami intimidasi baik secara fisik maupun mental sebanyak $80 \%$. Terdapat 457 kasus pelecehan seksual dan kekerasan pada anak yang terjadi di Provinsi Kalimantan Timur, diantaranya terdapat kasus bullying sepanjang tahun 2015 lalu. Siswa usia remaja di Kota Samarinda sebanyak 23\% memiliki tingkat bullying yang tinggi. Tujuan dari penelitian ini adalah melakukan mapping school bullying di sekolah dasar negeri Kota Samarinda tahun 2016. Metode penelitian ini adalah deskriptif untuk melihat pola sebaran school bullying di Kota Samarinda. Lokasi penelitian ini di Kota Samarinda, dimana responden berasal dari 30 sekolah dasar negeri di 10 kecamatan. Penentuan sekolah dasar yang menjadi lokasi penyebaran angket ditentukan oleh UPTD setempat. Data diolah menggunakan bantuan Epi Info pada menu Epi Map. Besar sampel yang digunakan sebagai responden berjumlah 1.491 yang terdiri dari siswa laki laki dan perempuan. Sebaran angka school bullying dimuat kedalam peta Samarinda yang terbagi menjadi 10 kecamatan. Peta menggambarkan angka berdasarkan chloropeth dan dot density per wilayah. Pelaku school bullying mencapai 544 anak dan korban school bullying 769. kecamatan dengan pelaku tertinggi adalah Samarinda kota yakni 43.50\% dan kecamatan dengan korban tertinggi adalah Sambutan yakni 57,50\%. Berdasarkan hal ini maka perlu pembentukan tim satuan anti penindasan di sekolah dapat dilakukan oleh pihak sekolah agar menjadi wadah pengawasan terhadap kejadian school bullying.
\end{abstract}

Kata Kunci : Kesehatan Mental, Pola Sebaran, Anak-Anak 


\section{PENDAHULUAN}

Fenomena tindak kekerasan dalam dunia pendidikan saat ini merupakan hal yang sering dihadapi. Salah satu bentuk tindakan kekerasan yang dapat menimbulkan dampak serius bagi peserta didik adalah penindasan (bullying). Eleni (2014) dan Bauman (2008) menjelaskan bahwa penindasan (bullying) adalah proses pelecehan dan tindakan kekerasan yang dilakukan oleh seseorang atau lebih secara berulang- ulang, sehingga korban berada dalam keadaan tidak mampu mempertahankan diri untuk melawan tindakan negatif yang telah diterima.

Berdasarkan laporan United Nations Development Programme (2014) hanya 44 negara dari 133 negara yang disurvey menerapkan inisiatif skala besar untuk melakukan pencegahan perilaku penindasan bagi anak usia sekolah. UNICEF (2009) telah menjelaskan bahwa $80 \%$ dari siswa sekolah dasar telah mengalami intimidasi baik secara fisik maupun mental dan mayoritas terjadi di kelas. Hal ini menurut Wicaksana (2008), dapat menyebabkan siswa merasa takut, tertekan hingga mengalami depresi.

Di Indonesia Undang-undang RI Nomor 20 tahun 2003 dalam pasal (1) ayat (1) telah menyebutkan bahwa "pendidikan adalah usaha sadar dan terencana untuk mewujudkan suasana belajar dan proses pembelajaran agar peserta didik secara aktif mengembangkan potensi dirinya untuk memiliki kekuatan spiritual, keagamaan, pengendalian diri, kepribadian, kecerdasan, akhlak mulia, serta keterampilan yang diperlukan dirinya, masyarakat, bangsa dan negara"(Pemerintah Indonesia, 2003) . Guna ketercapaian tujuan tersebut Widayanti dan Siswati (2009) dan Damantari (2011) berpendapat bahwa setiap sekolah perlu menciptakan situasi belajar yang kondusif, jauh dari tindakan kekerasan, serta menanamkan nilai-nilai positif dalam bersosialisasi.

Pada kenyataannya, Saat ini Indonesia menduduki peringkat kedua terbesar setelah Jepang untuk kasus bullying atau kekerasan pada anak di sekolah (Indra, 2015) . Data Global School-based Student Health Survey (GSHS) menunjukkan bahwa grafik kasus bullying di Indonesia mengalami peningkatan sejak tahun 2007, sekitar $40 \%$ murid berusia 13-15 tahun di Indonesia melaporkan telah diserang secara fisik selama 12 bulan terakhir di sekolah mereka. Laporan Komisi Perlindungan Anak Indonesia (KPAI) terbaru tahun 2013 menunjukkan bahwa terdapat 1.051 anak menjadi korban kekerasan di Indonesia dan $70 \%$ anak-anak usia $8-12$ pernah menjadi pelaku kekerasan atau bullying di sekolah.

Perilaku bullying siswa menurut Saputro (2013), Eleni (2014) dan Kholilah (2012) dipengaruhi oleh tingginya paparan perilaku kekerasan yang diterima baik melalui media massa, lingkungan keluarga dan teman sebaya, sehingga anak berpotensi menjadi lebih agresif, pemberani, suka melawan, dan mencari dukungan sosial untuk melakukan bullying kepada teman sekolah yang mereka anggap lemah dan mudah untuk ditindas.

Anak korban bullying cenderung untuk mengalami gejala somatisasi lebih tinggi dibanding dengan anak-anak yang lain. Sakit kepala berulang hingga sulit tidur merupakan contoh-contoh gejala somatisasi yang dapat terjadi. Bahkan dapat mengakibatkan anak korban penindasan menjadi takut untuk bersekolah dan mempengaruhi tingkat absensi anak di sekolah (Dwipayanti dan Indrawati, 2014). Sedangkan menurut Tsarigan (2016) siswa yang mengalami bullying di sekolah akan dikucilkan dan dibenci oleh teman sekitarnya. Hal ini akan berdampak pada perkembangan potensi siswa di masa yang akan datang.

Kalimantan Timur sebagai salah satu provinsi di Indonesia berdasarkan laporan BPPKB Provinsi menunjukkan bahwa terdapat 457 kasus pelecehan seksual dan kekerasan pada anak, dan diantaranya juga terdapat kasus bullying atau intimidasi, sepanjang tahun 2015 lalu. Penelitian yang dilakukan oleh Amrina (2013) menjelaskan bahwa 23\% siswa SMPN 31 Samarinda memiliki tingkat bullying tinggi, $39 \%$ tingkat bullying sedang. Usia rentan menjadi korban bullying menurut Sejiwa (2008) adalah usia remaja yaitu sekitar 13-18 tahun, dimana dalam periode tersebut dianggap sebagai masa yang sangat penting dalam kehidupan seseorang khususnya dalam pembentukan kepribadian. Sehingga sebelum memasuki usia remaja, seorang anak harus dibekali pengetahuan serta pemahaman terkait bahaya tindakan bullying pada usia sekolah dasar. Hal ini juga ditegaskan oleh Liu dan Graves (2011) bullying dapat terjadi pada semua tingkat usia, tetapi mulai meningkat pada akhir sekolah dasar, puncak di sekolah 
menengah, dan umumnya menurun di sekolah tinggi.

Pusat Data dan Statistik Pendidikan Kementrian Pendidikan dan Kebudayaan (2015), menunjukkan bahwa jumlah sekolah dasar (SD) di Samarinda memiliki proporsi terbanyak dibandingkan dengan jenjang pendidikan lainnya, yaitu sebanyak 248 sekolah dengan total jumlah siswa sebanyak 91.614 orang. Samarinda dalam dalam hal ini, belum memiliki data resmi dan spesifik terkait kasus atau pelaku bullying di lingkungan pendidikan. Dalam hal ini, anak usia sekolah merupakan investasi bangsa dan kualitas bangsa di masa depan ditentukan dari kualitas fisik dan psikologis anak-anak saat ini.

Perilaku saling menindas yang dilakukan oleh siswa-siswi sekolah di Samarinda sering terjadi pada saat jam istirahat, di kantin, di ruang pertemuan tetapi hal tersebut hanya dilakukan sebatas ejekan dan bukan tindakan yang menyakiti orang lain. Beberapa grup atau kelompok siswa senior yang berperilaku kurang baik, seperti memberikan julukan tertentu, memukul, mendorong (Saifullah, 2016).

Tingginya populasi siswa sekolah dasar dan besarnya potensi kejadian bullying di Samarinda perlu dijadikan perhatian oleh berbagai pihak khususnya lembaga pemerintah daerah dalam menyusun rencana program guna pencegahan tindak kekerasan dan penindasan terhadap anak-anak. Penelitian ini penting untuk dilaksanakan sebagai bahan referensi yang mencakup informasi perilaku bullying siswa-siswi sekolah dasar negeri di wilayah kota Samarinda, perlu dilakukan pemetaan risiko dan potensi kasus bullying sebagai acuan dasar perencanaan sehingga program-program pemerintah maupun lembaga terkait dapat lebih tepat sasaran dan sesuai dengan kebutuhan serta tingkat keparahan fenomena bullying pada masing-masing sekolah dasar di Kota Samarinda. Sehingga tujuan umum dari penelitian ini adalah mapping school bullying di sekolah dasar negeri Kota Samarinda dengan mengidentifikasi angka kecenderungan pelaku, korban dan pelaku dan korban school bullying di sekolah dasar negeri di Samarinda tahun 2016.

\section{METODE}

Berdasarkan jenis data yang dikumpulkan penelitian ini merupakan jenis survei data kuantitiatif dengan pendekatan deskriptif karena hasil yang diperoleh akan disajikan dalam bentuk peta, grafik dan tabel untuk melihat hasil identifikasi perilaku school bullying pada siswa/i sekolah dasar negeri di kota Samarinda. Peta school bullying akan diolah menggunakan bantuan software Epi Info.

\section{HASIL DAN PEMBAHASAN}

Adapun hasil dan pembahasan penelitian dapat dilihat sebagai berikut:

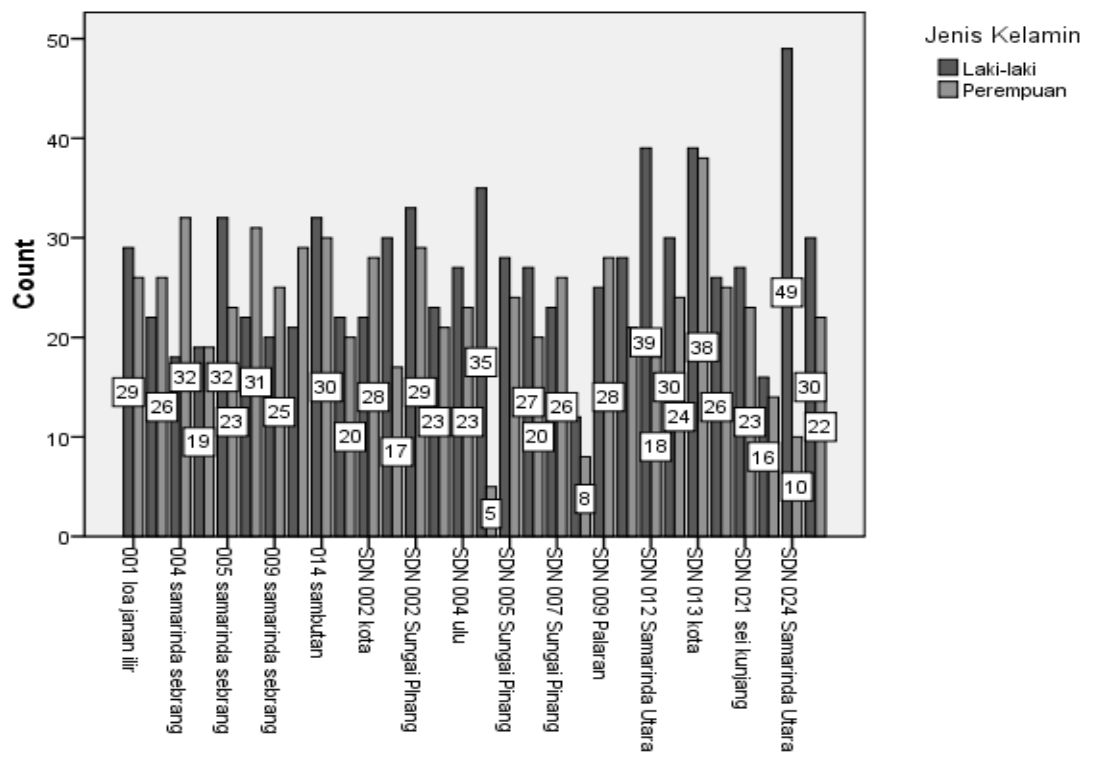

Gambar 1. Grafik Distribusi Siswa/i berdasarkan jenis kelamin dan asal sekolah 
Berdasarkan data grafik 1 diketahui bahwa jumlah sekolah yang menjadi subjek dalam penelitian ini adalah sebanyak 30 sekolah dasar negeri di Kota Samarinda dan jumlah responden adalah sebanyak 1.491 orang, dengan jumlah laki-laki sebanyak 806 orang dan perempuan sebanyak 685 orang. Penelitian ini berlokasi di Kota Samarinda yang terdiri dari 10 kecamatan. 10 kecamatan tersebut memiliki kondisi geografis, fasilitas dan jumlah penduduk yang berbeda-beda.

Nickerson (2014) menjelaskan bahwa jenis kelamin berperan dalam kejadian bullying dan hubungan antara pelecehan antar teman sebaya karena anak laki-laki lebih berpeluang untuk melakukan bullying fisik. Sebaliknya anak perempuan cenderung untuk terlibat dalam bullying sosial, atau inklusi dan eksklusi pada teman-temannya. Selain itu menurut penelitian yang dilakukan oleh Susan (2013)diketahui bahwa ada hubungan antara kejadian bullying dengan jenis kelamin pada anak. Jenis kelamin laki-laki berada pada tingkat yang lebih tinggi terhadap perlakuan tindakan bullying kepada siswa lain yaitu sebanyak $6 \%$, sedangkan tingkat perlakuan bullying pada siswi perempuan sebanyak 4-5\%.

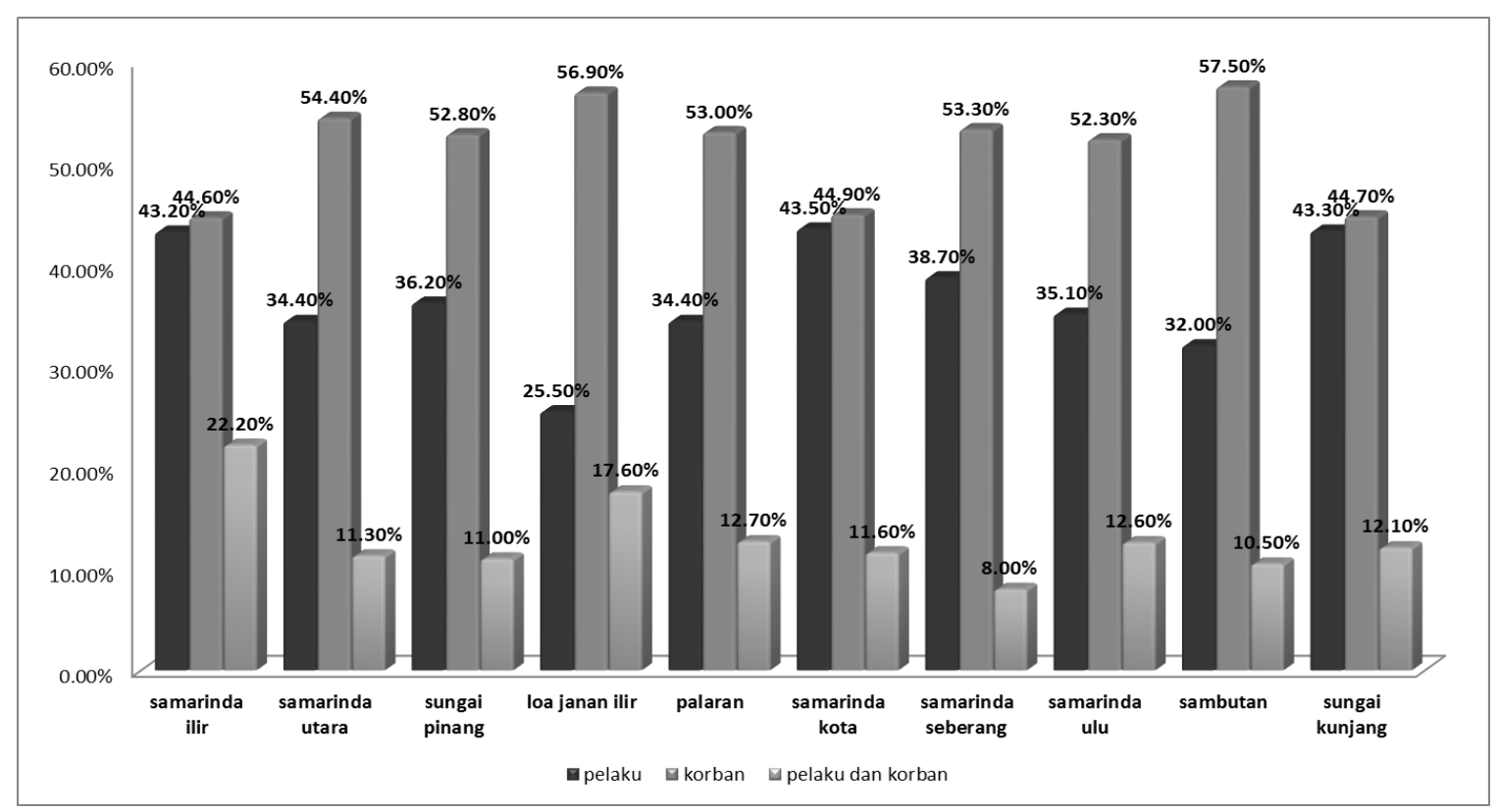

Gambar 2. Persentase Pelaku, Korban dan Pelaku sekaligus Korban School bullying Kota Samarinda

Berdasarkan gambar 2 diketahui bahwa persentase jumlah pelaku school bullying tertinggi terdapat di wilayah Kecamatan Sambutan yaitu sebesar $57.50 \%$, Kecamatan Loa Janan Ilir yaitu sebesar $56.90 \%$ dan Kecamatan Samarinda Utara yaitu sebesar 54.4\%. Angka persentase korban school bullying tertinggi terdapat di wilayah Kecamatan Samarinda Kota adalah sebesar 43.5\%, Kecamatan Sungai Kunjang adalah sebesar $43.3 \%$ dan Kecamatan Samarinda Ilir adalah sebesar $43.2 \%$ Hampir sebagian besar dari pelaku bullying melakukan tindakan penindasan secara verbal dengan mengejek, mengolok-ngolok, memanggil siswa lain dengan panggilan yang buruk. Coloroso (2006) dalam hal ini menjelaskan bahwa bentuk penindasan secara verbal dapat berupa pemanggilan julukan nama yang tidak baik, celaan, fitnah, kritik, ancaman, penghinaan rasial dan berkata-kata yang melecehkan orang lain khususnya yang berkaitan dengan aspek seksual. Adanya kecenderungan fenomena bullying mulai terjadi pada anak-anak sekolah dasar. Diyakini, kecenderungan tersebut diakibatkan oleh adanya perilaku modeling pada tahap perkembangan psikologis anak usia sekolah dasar (Tumon, 2017).

Dalam Suwarni (2009), diketahui bahwa terdapat perbedaan nilai agresivitas antara remaja laki-laki dibandingkan perempuan di mana laki-laki lebih cenderung lebih agresif dalam pola pertemanan, Sehingga terkadang perempuan mengalami berbagai ketidakadilan 
contohnya perasaan bersalah, kekerasan fisik, marginalitas, dan beban ganda lainnya. Imron (2012) pun menegaskan bahwa perempuan seringkali mengalami kerugian akibat kondisi lingkungan sosial seperti ejekan, cemoohan, celaan dan sebutan-sebutan negatif lainnya yang merupakan bentuk kekerasan psikis terhadap perempuan.

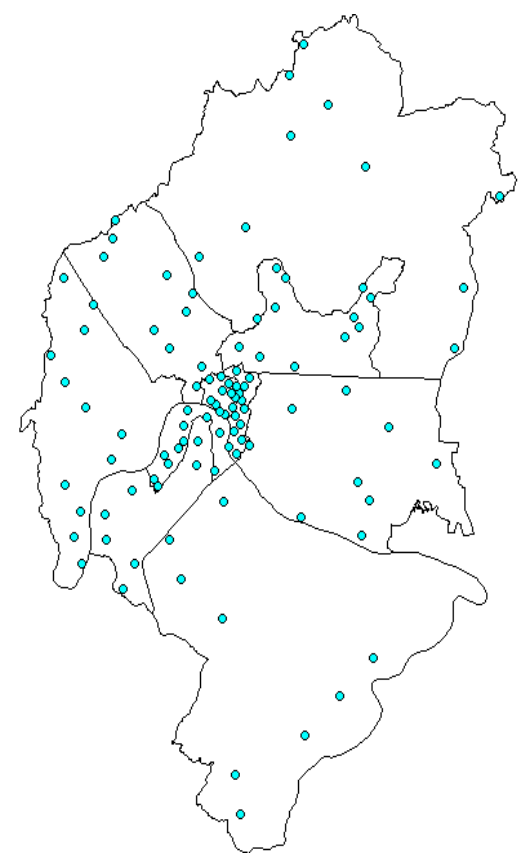

Legend - pelaku_bullying 1 Dot $=5$

Gambar 3. Peta Dot Density Pelaku Bullying (1 dot =5)

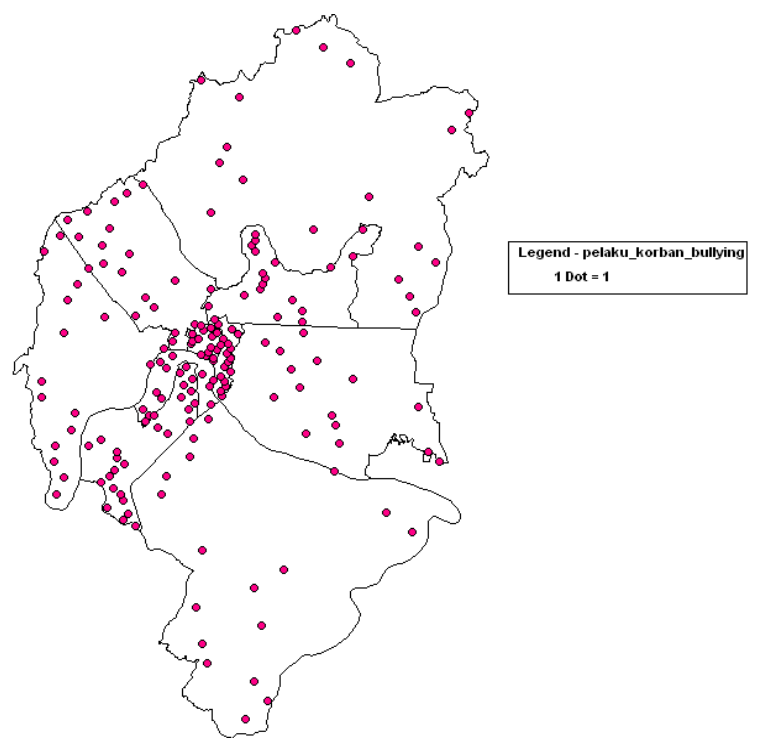

Gambar 4. Peta Dot Density Pelaku dan Korban Bullying (1 dot=1) 


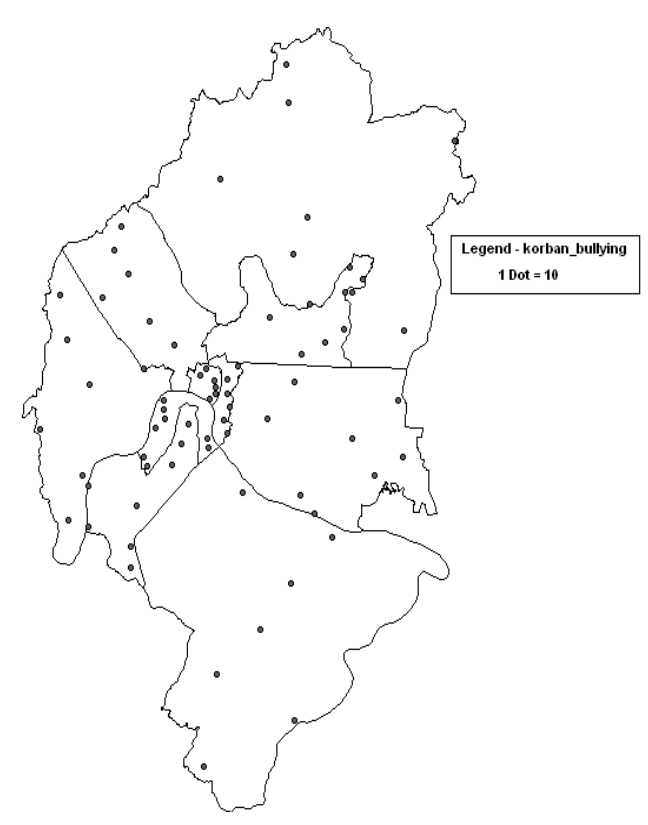

Gambar 5. Peta Dot Density Korban Bullying (1 dot=10)

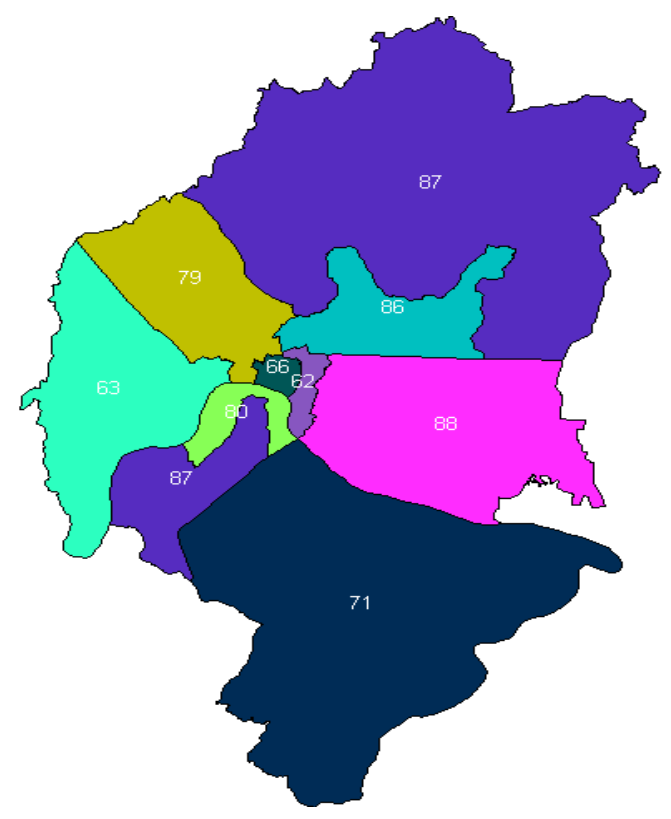

Gambar 6. Sebaran Kecenderungan Korban Scholl Bullying

Perangkat epi map digunakan untuk membantu peneliti dalam melihat pola sebaran angka school bullying pada siswa/i di sekolah dasar negeri kota Samarinda. Sebaran tersebut dapat dilihat dengan penggunaan warna berbeda sesuai angka school bullying, atau menumpuk warna dan angka serta titik (dot) pada masing masing kecamatan di kota
Samarinda. Pada prinsipnya, tampilan atau penyajian pada peta dengan menggunakan bantuan Epi Info versi 3 ini tidak lebih baik dari program pemetaan yang banyak dimanfaatkan oleh kaum akademisi ataupun peneliti dan praktisi, tetapi Epi Map bisa menjadi salah satu alternatif yang baik untuk diterapkan secara 
luas di bidang kesehatan masyarakat demi membantu penyajian data yang lebih baik.

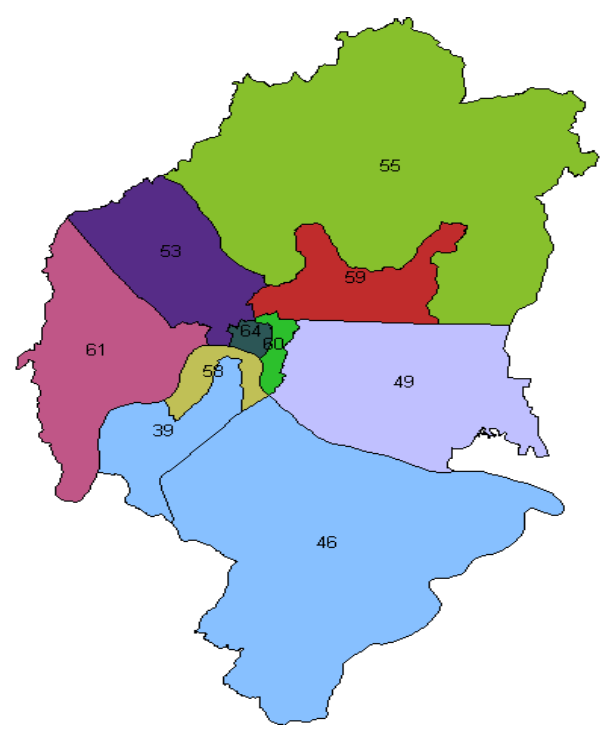

Gambar 7. Peta Sebaran Kecenderungan Pelaku School Bullying

Pada 10 kecamatan yang dilakukan penelitian, dapat dilihat bahwa hampir seluruh responden menjawab pernah melakukan tindakan bullying secara verbal, sedangkan tindakan bullying secara fisik, tidak sedikit yang menjawab mereka dapat dengan mudah mendorong, memukul dan menendang teman lainnya saat bermain hingga kadang menimbulkan perkelahian. Hal ini menurut Tridhonanto dalam Indanah (2016) bahwa Tindakan bullying sekolah tidak sama dengan pertengkaran yang umumnya terjadi pada anak sekolah. Pertengkaran tersebut sebagai hal normal dan membuat anak belajar cara bernegosiasi dan bersepakat satu sama lain.

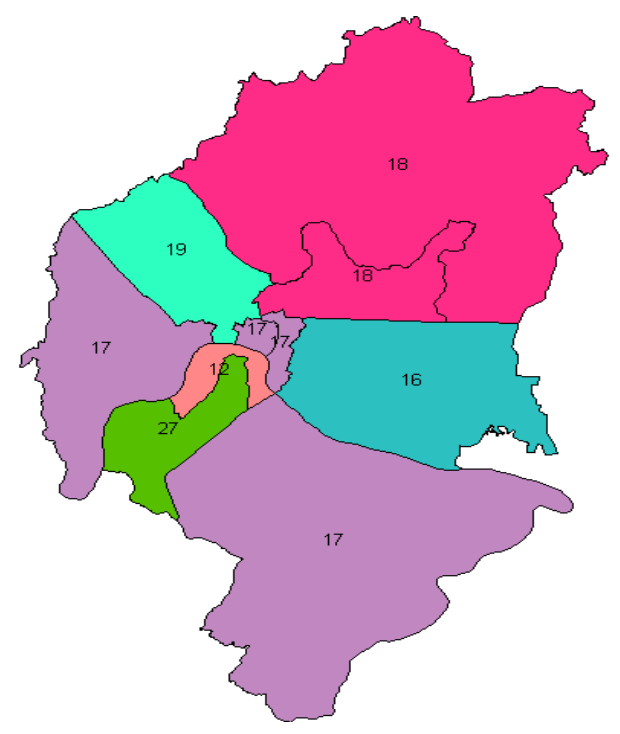

Gambar 8. Sebaran Kecenderungan Korban dan Pelaku School Bullying

Beberapa dampak yang dapat terjadi apabila pelaku bullying cenderung mengalami peningkatan di Kota Samarinda adalah menurunnya kualitas kesehatan mental generasi siswa-siswi sekolah dasar khususnya di lingkungan sekolah. Meningkatnya angka perselisihan hingga kriminalitas dalam bentuk kekerasan di usia sekolah dasar. Sekolah justru dapat menjadi tempat berlatih untuk bertindak negatif maka iklim sekolah seperti ini akan 
merusak dan bahkan menghancurkan masa depan emas anak-anak di Kota Samarinda. Padahal sekolah adalah tempat pembentukan karakter generasi muda, dan guru merupakan salah satu komponen yang paling penting dalam hal ini. Sehingga penting kiranya meningkatkan peran dan partisipasi guru-guru sekolah dasar negeri di Samarinda dalam mengawasi pola perilaku kekerasan oleh siswa-siswi di sekolah.

\section{KESIMPULAN}

Jumlah keseluruhan siswa/i yang cenderung sebagai pelaku school bullying adalah 544 anak, sedangkan jumlah siswa/i yang cenderung sebagai korban adalah 769 anak, dan siswa/i yang cenderung pada keduanya yakni sebagai pelaku dan korban adalah 178 anak. Jumlah pelaku school bullying tertinggi berada di Kecamatan Samarinda Kota yakni 43.50\%, korban school bullying di Kecamatan Sambutan yakni $57.50 \%$, pelaku dan korban di kecamatan Samarinda Ilir $22.20 \%$. Sebaran siswa/i yang cenderung sebagai pelaku di Kecamatan Sungai Kunjang, Samarinda Seberang, Samarinda Kota, Samarinda Ilir, dan Sungai Pinang memiliki angka di antara 58 hingga 64 anak, serta 5 kecamatan ini dilihat dari peta Samarinda letaknya cenderung berdekatan. Sebaran siswa/i yang cenderung sebagai korban di kecamatan sambutan, Samarinda Utara dan Loa Janan Ilir dengan angka mencapai 87 hingga 88 anak. Berdasarkan letak, tiga kecamatan ini berada tidak berdekatan. Sebaran siswa/i yang cenderung pada kedua perilaku, yakni pelaku dan korban school bullying hampir merata pada semua kecamatan kecuali di lokasi Loa Janan Ilir yang mencapai 27 anak

\section{SARAN}

Pihak sekolah dapat membentuk tim satuan anti penindasan (TINDAS) di tingkat siswa dan guru berperan sebagai tim pengawas dari pelaksanaan sistem keamanan dalam hubungan sosial siswa khususnya pada jam-jam tertentu contohnya saat istirahat, pergantian jam dan sebelum atau sesudah masuk ke dalam kelas. Selain itu, orang tua dan masyarakat diharapkan dapat meningkatkan pengawasan dan kepekaan dalam memberikan batasan yang jelas tentang tingkah laku yang dilarang (permissive parenting).

\section{DAFTAR PUSTAKA}

Amrina. 2013. Pengaruh bullying terhadap motivasi belajar siswa kelas VII di SMPN 31 Samarinda. Skripsi, Universitas 17 Agustus 1945, Samarinda.

Bauman, S. 2008. The role of elementary school counselors in reducing school bullying. Elementary School Journal, 108(5), pp. 362-375. doi: $10.1086 / 589467$.

Coloroso, B. 2006. Penindas, Tertindas, dan Penonton. Resep Memutus Rantai Kekerasan Anak dari Prasekolah Hingga $S M U$. Jakarta : Serambi.

Damantari, D. 2011. Perilaku Bullying Pada Remaja Di Sekolah Ditunjau Dari Jenis Kelamin. Skripsi, Universitas Muhammadiyah, Surakarta.

Dwipayanti, I. A. S. dan Indrawati, K. R. 2014. Hubungan Antara Tindakan Bullying dengan Prestasi Belajar Anak Korban Bullying pada Tingkat Sekolah Dasar. Jurnal Psikologi Udayana, 1(2), pp. 251-260.

Eleni, P. 2014. School Bullying: The Phenomenon, the Prevention and the Intervention. Procedia - Social and Behavioral Sciences. doi: 10.1016/j.sbspro.2014.09.193.

Imron, A. 2012. Pendidikan Kesehatan Reproduksi Remaja Peer Educator \& Efektivitas Program PIK-KRR di Sekolah. Ar-ruzz Media: Yogyakarta.

Indanah. 2016. Peran Pengawasan Orang Tua dan "Peer Group" terhadap Kejadian "Bullying".

Indra, Z. 2015. Indonesia Ranking Kedua Bullying Sedunia - Tribun Pekanbaru, Tribun Pekanbaru.

Kholilah, M. 2012. Hubungan Tingkat Pengetahuan Remaja Tentang Bullying dengan Perilaku Bullying pada Siswa Kelas XI Di SMA Semen Gresik. Skripsi:Stikes Yarsi. Tidak Dipublikasikan.

Liu, J. dan Graves, N. 2011. Childhood bullying: A review of constructs, concepts, and nursing implications. Public Health Nursing, 28(6), pp. 556-568. doi: 10.1111/j.1525-1446.2011.00972.x.

Nickerson, A. 2014. Bullying and Suicide: Get the Facts. Bullying and Teasing. 
Pemerintah Indonesia. 2003. Undang-Undang Republik Indonesia Nomor 20 Tahun 2003.

Pusat Data Dan Statistik Pendidikan Kementrian Pendidikan dan Kebudayaan. 2015. Data Referensi Pendidikan Dan Kebudayaan. Diakses dari: https://www.referensi.data.kemdikbud.go. id.

Saifullah, F. 2016. Hubungan Antara Konsep Diri Dengan Bullying Pada Siswa-Siswi Smp. eJournal Psikologi, 4(2), pp. 200-214.

Saputro, A. 2013. Hubungan Paparan Kekerasan dengan Perilaku Bullying di Sekolah Dasar. Skripsi, Universitas Muhammadiyah, Surakarta.

Sejiwa. 2008. Bullying: Mengatasi Kekerasan di Sekolah dan Lingkungan Sekitar Anak. Jakarta: Grasindo.

Susan P. Limber, Ph.D., Clemson University and Olweous, P. \& \& U. H. 2013. Bullying in U.S. School: 2012 .Status Report. Hazelden Foundation.

Suwarni. 2009. Orangtua Sahabat Anak Dan Remaja. Cerdas Pustaka : Yogyakarta.

Tarigan, B. 2016. Meningkatkan Rasa Empati kepada Sesama Teman dalam Mengurangi Perilaku Bullying melalui Bimbingan Kelompok Teknik Diskusi Di Kelas XI IPS SMA Yapim Air Bersih Medan Tahun Ajaran 2015/2016. Skripsi, Universitas Negeri Medan.

Tumon, M. B. A. 2017. Studi Deskriptif Perilaku Bullying pada Remaja Matraisa. CALYPTRA, 3(1), pp. 1-17.

UNICEF. 2009. Stop violence against children. UNICEF Malaysia Communications. doi: 10.2174/138920312803582960.

United Nations Development Programme, and the U. N. O. on D. and C. 2014. New Study Highlights Need to Scale up Violence Prevention Efforts Globally, World Health Organization Report.

Wicaksana, I. 2008. Mereka Bilang Aku Sakit Jiwa. Jakarta : Kanisius.

Widayanti, C. G. dan Siswati, S. 2009. Fenomena bullying di sekolah dasar negeri di semarang: sebuah studi deskriptif. Junal Psikologi Undip, 5(2). 